\title{
Dimensions and Factors of Contemporary Geography Learning Climate at Senior High School
}

\author{
Mukminan \\ Received: April 2018 / Accepted: June 2018 \\ (๑) 2018 Faculty of Geography UGM and The Indonesian Geographers Association
}

\begin{abstract}
This study develops the dimensions and factors of the learning climate of contemporary geography at the senior high school through the process of Exploratory Factor Analysis (EFA). This research uses Research and Development (R \& D). Research respondents involved 595 experts and practitioners of geography learning in Yogyakarta, determined using stratified-purposive sampling. The calculation results give the average value of Aiken logical validity of 0.85 , the value of Measure of Sampling Adequacy of 0.789 , Bartlett's test of sphericity $0.000<0.05$, a Chi square of 37.6 with $\mathrm{df}=25$, p. value $=0.05061$, RMSEA of $0.058<0.08$, and a t value of $4.78>1.96$ and with a significance level of $5 \%$. These calculations have been eligible for EFA analyses. The results classify the geography learning climate into four dimensions with 16 factors. The dimensions are: (1) Student-centered learning, (2) positive relationships among students, (3) positive relationships between teachers and students, and (4) developing and strengthening classroom rules. Each dimension consists of $6,4,2$, and 4 factors.
\end{abstract}

Keywords: learning climate, contemporary geography learning

\begin{abstract}
Abstrak Studi ini mengembangkan dimensi dan faktor iklim pembelajaran geografi kontemporer pada jenjang Sekolah Menengah Atas melalui proses Exploratory Factor Analysis (EFA). Penelitian ini menggunakan metode Penelitian dan Pengembangan (RßD). Responden penelitian melibatkan 595 pakar dan praktisi pembelajaran geografi di Yogyakarta, yang ditetapkan menggunakan stratified-purposif sampling. Hasil perhitungan diperoleh rerata nilai Aiken logical validity yaitu 0, 85. nilai Measure of Sampling Adequacy 0,789, Bartlett's test of sphericity 0,000 < 0,05, chy square 37,6 dengan df 25, p-value 0,05061, RMSEA 0,058<0,08, dan nilai $t=4.78>1,96$ signifikansi 5\%. Hasil perhitungan tersebut telah memenuhi syarat analisis EFA. Hasil perhitungan tersebut mengelompokkan iklim pembelajaran geografi menjadi empat dimensi dengan 16 faktor. Dimensi yang terbentuk, yaitu: (1) Pembelajaran berpusat kepada siswa, (2) hubungan positif antar siswa, (3) hubungan positif antara guru dan siswa, dan (4) mengembangkan dan memperkuat aturan kelas. Setiap dimensi terdiri atas 6, 4, 2, 4 faktor.
\end{abstract}

Kata kunci: iklim pembelajaran, geografi, kontemporer

\section{Introduction}

The concept of geography as a science has continuously developed and experienced paradigmatic expansion towards more detailed and practical directions. Worosuprojo [2013] in Suhardjo [2013)] states the development of science provides new perspective for geography in the development of methodology, analyzes, and scientific frame of thinking that are dynamic. Meanwhile, according to Riyanto [2013] in Suhardjo [2013] the development of Geography as a systematic science, has placed Geography as a science whose existence is increasingly needed by the community because in the praxis level has an increasingly greater opportunity to engage as an applied science that important contribution for development

Hopkin [2011] states that geography teachers teaches about developmental changes that lead a citizen to be literate of the inter-connected nature of the global

\footnotetext{
Mukminan

Department of Geography Education, Faculty of Social Sciences, Yogyakarta State University, Yogyakarta, Indonesia

Corespondent email: mukminan@uny.ac.id.
}

world. Lambert and Morgan [2010] mentions that modern geography is predicted to be able to create an era of harmony and stability through a focus of its space analysis and man's activities on earth. The physiographical description of a region depicting the stretch of land, water, and air, as well as the social phenomena, in which there are living and non-living things that interact with each other, currently becomes the extension of the geographical study. This condition must rightly be known and understood by the society in the effort of conserving the nature of their living place. Efforts of conservation can be given programmatically through the school environment by integration in geography as well as other subject-matter learnings. Mahat et.al [2016] have developed a perennial school model in Malaysia using indicators that are developed from the concepts and scopes of geography. Meanwhile, Mohan et.al [2015] explain that geography is a complex science discipline that focuses on the characteristics, relationships, and spatial patterns of the activities of man and nature. Geography teaches about cultures, geopolitics, system of nature, resource distribution and uses, and the mapping of spatial data in order to 
understand more about the world. Withers, [2009] adds that geography cannot be detached from the processes of time and "place" as one of the fundamental concept in geography. Janelle and Goodchild [2010] state that geography does not only utilize conventional maps in explaining a phenomenon, but it can right now also make use of processes and images of the geographical information systems. The geographical dimensions as a product of learning have been clarified by Anthamatten [2010], and Lee and Bednarz [2012], in that studying geography is designated for the students to develop competencies in the spatial aspects.

Jo and Bednarz [2014] give the illustration of spatial aspects as the basic characteristic of geography thinking construction blocks. The application of spatial concepts such as location, distance, scales, distribution, and patterns makes spatial thinking a specific form of geographical thinking as a frame to understand, manage, and solve problems. They add that geography is a powerful tool to explain the world in all scales, local to global. Jo dan Bednarz [2010] divides this thought into three components in line with the National Research Council of the US [2006], namely: the concepts of space, the tools of representation, and cognitive processes.

The foregoing discussions show that the scope of geography has experienced extension. This dynamics of meaning is currently adopted and adapted in the learning of geography in the senior high school in Indonesia, such that the context is contemporary geography learning. Innovation in the directions of geography learning can be seen in the achievement of the curriculum documents which present information of geography analyses to the learners in a holistic way by way of representations of spatial objects in the real world.

In the syllabi [Kemdikbud, 2016: 5-6], it is implicitly represented that the competencies in the learning of geography are formulated in the geographical views of the relationships among men and the environments in three dimensions. Geographical views towards the dynamics of the physical environment and social environment can be seen from the integrative aspects of space and space interdependences both among spaces and among scales. This perspective can be realized in concrete or abstract forms through visual, verbal, mathematical, digital, or cognitive thought patterns.

Achievement of geography learning objectives will depend on the low or high quality of the learning climate. There are several terms that are equivalent to the term of learning climate in the learning context such as situation, atmosphere, and environment, that describes the condition, influence, and external stimuli on the implementation of teaching and learning or instructional process or activity. Cox [2006] and Kirby et.al [2013] state that positive interaction among, teachers, students, and environments will produce impressive learning climates and carry on conducively and effectively. Instructional components are ever interactive and support one another in an instructional system. Davidson [2002] states the most relevant classroom instruction for geography learning that uses this principle is one that applies the inquiry method. This does entail that other learning methods such as the co-operative method, active method, quantum method, and the like cannot be applied. The inquiry method asks the learners to analyze the spatial relations among phenomena and processes on the earth surface. The learning processes can facilitate learners to be able to understand problems, identify factors and causes, formulate findings in the descriptive format, and draw conclusions. According to Rawling [2000], the inquiry processes must be integrated within the skill development of geography.

Seen from the lesson plans of the geography classes in schools in Yogyakarta, the climate of this scientificbased learning is not yet apparent in all the activities of observing, problem formulation, data collection, analysis, and product presentation. Nursa'ban [2012] reports a finding where classes look monotonous, with teachers taking the dominant roles as sources of information. Mukminan [2011] shows that teachers are still obstructed lack of mastery of the subjectmatter material as prescribed in the basic curricular competences.

Learning climate is understood as one of the primary factors for looking at the quality of learning. By the rationales of the extension of geography, learner-centered orientation, and paradigm changes in learning climate, the present writer proposes that the dimensions and climates of geography learning as indicators of learning qualities need to be explored more deeply. Analyses of these dimensions and climates of geography learning can give an accurate and comprehensive confirmation on the quality of the instructional processes in geography learning in the senior high school.

\section{The Methods}

The present article is based on the findings of the research and development study using Sukmadinata's [2005] model in three phases: preliminary, development, and feasibility. In the preliminary phase, a literary study was conducted to obtain a grand theory of geography and learning climate. This was followed up by a focusgroup discussion to build up geographical learning climates based and theories and field needs. In the development phase, the design and development were conducted of learning climates through two try-outs to finalize the product and its validation. In the feasibility phase, the product feasibility was tested by operational field try-outs in four schools in Yogyakarta. In the research description, the study was aimed at identifying the dimensions and factors related to geography learning climates in operational and measurable statements. The study involved 595 subjects, experts and practitioners. The experts were those who were proficient in geography 
learning and materials. The practitioners were school principals, supervisors, teachers, and students. Data were obtained through questionnaires and documents. They were analyzed using the SPSS computer programs for an Aiken validity count and an exploratory factor analysis. Results were displayed in percentages taken from the respondents' answers. Quantitative data were subsequently converted back into qualitative information according to the predetermined criteria and were ultimately interpreted.

\section{Results and Discussion}

Dimensions of Learning Climates of Contemporary Geography

The literary reviews for the development of the constructs of learning climates of contemporary geography instruction were obtained from a number of sources and experts, starting from Rohani [2004] who explains that learning climate is built of good interactions among teachers, students, reward systems for achievement, supportive students' behaviours, disciplined practices, collaborative leaderships, collaboration among teachers, professional developments, collegial supports, and mutual objectives. Opinion of the same tone is put forward by Falsario [2014] who states that a classroom climate refers to a composite of variables working together to promote learning in a comfortable environment in a classroom. Every classroom is unique because there is a wide range of variables that have an impact on the climate in a classroom. However, a number of elements are required for the establishment of a successful learning environment. The most important thing for a classroom is to create an climate promoting learning. Mucherah [2003] distinguishes three classroom dimensions in learning, namely: relationship, personal growth, and system maintenance and change. The relationship dimension identifies the nature and intensity of personal relationships within the environment and assesses the extent to which teachers and students are involved in the environment and support and help each other. The personal growth dimension assesses basic directions along which personal growth and self-enhancement tend to occur. The dimension of system maintenance and change assesses the extent to which the environment is orderly, clear in expectations, maintains control, and is responsive to change. Glaser [1962] in Rusman [2010] places four aspects of classroom learning climate, namely: instructional objectives, entering behaviour, instructional procedures, and performance assessment.

Based on the theoretical reviews and the focusgroup discussions, the writer designed and developed 16 items of factors regarded to be relevant with the quality of climates of geography learning in the contemporary curriculum. In the results of the product try-out validation, the content validity of the 16 factors is in the "very good" category so that the factors can be constant. Next, to obtain the climate dimensions of the geography learning quality, Exploratory Factor Analysis (EFA) was computed during the product try-out. The analysis was started by computing the Kaiser-Meyer-Olkin (KMO) and an input variable was obtained at $0.595>0.50$, a Bartlet's test index was below the cutscore of $0.05(0.000$ $<0.05$ ), and most had anti-image correlation indexes of 0.3 . These computation results indicated that the observation data were feasible to be further subjected to factor analyses.

From the calculation results of the Total Variance Explained (TVE), scores were obtained of the percentage values of construct variances to explain the division of the dimensions for each factor. The number of the dimensions to be formed could be found from the eigenvalues of $>1$ to become 1 factor. Initial computation of eigenvalues cumulatively reduced 16 factors into 1 explaining 55.909\% of variance, into 2 factors explaining $66.365 \%$ of variance, into 3 factors explaining $74.190 \%$ of variance, and into 4 factors explaining $80.367 \%$ of variance. The initial eigenvalues grouped all the factors into 4 dimensions. These calculation results gave the indication that the components to measure the learning climate variable fulfilled the pre-requisite of uni-dimension.

In order to clarify the resulted number of factors and inter-correlation among the factors, the Anti-Image Correlation (AIC) and Rotated Component Matrix (RMC) were conducted; in line with Mooi \& Sarstedt [2014] that an indicator or item could be regarded as having a high validity toward the construct when the loading factor $\geq 0.3$. Results of the analyses showed the 16 factor items having AIC values from the lowest to the highest 0.411 to 0.796 , while the RMC scores 0.625 to 0.871 . The factor items grouped into four dimensions and 16 factors for geography learning climates at the senior high school. Display of the dimensions and factors together with activities is given in Table 1 .

To see the strength of each factor item on the variable of learning climates, a LISREL analysis was conducted.

Results of the LISREL analyses as shown in Figure 2 give a chi-square score of 37.6 with a $\mathrm{df}=25$, $\mathrm{p}$-value $=0.05061$ (higher than 0.05), and RMSEA $=0.058$ (RMSEA value $\leq 0,08)$. Based on the statistic results, it can be stated that all items have fulfilled the analyses to be included into the "fit" category.

\section{Contribution of Learning Climate on Geography Learning}

The school is an institution that has the goal of educating and nurturing students by way of academic activities called learning. In the context of government efforts towards improving the quality of education in Indonesia and realizing the National Education Standards (Peraturan Pemerintah no.19 tahun 2003) which aims to assuring the quality of national education in order to educate the nation's life, building the character and civilization of nation prestige, 
Table 1. Factors and Indicators for SHS Geography Learning Climates

\begin{tabular}{|c|c|c|}
\hline Factor & Indicator & Activity \\
\hline $\begin{array}{l}\text { Student-centered } \\
\text { learning }\end{array}$ & $\begin{array}{l}\text { 1)Apply learning using exploration by } \\
\text { students } \\
\text { 2)Motivate autonomous learning } \\
\text { 3)Readiness-based grouping } \\
\text { 4)Individual/contextual learning } \\
\text { 5)Joy and fun in learning } \\
\text { 6)Lifeskill-oriented learning }\end{array}$ & $\begin{array}{l}\text { Apply geography skill activity: } \\
\text { 1.asking geographic questions } \\
\text { 2.acquiring geographic information } \\
\text { 3.organizing geographic information } \\
\text { 4.analyzing geographic information } \\
\text { 5.answering geographic questions }\end{array}$ \\
\hline $\begin{array}{l}\text { Positive relation } \\
\text { among students }\end{array}$ & $\begin{array}{l}\text { 1)Apply positive students' learning } \\
\text { behaviours (Mastery Goal Orientation) } \\
\text { 2)Appreciate students' relation by posi- } \\
\text { tive behaviours } \\
\text { 3)Develop relation in game playing that } \\
\text { encourages positive interaction } \\
\text { 4)Offer solution for students' social } \\
\text { dynamics in getting along and building } \\
\text { up relation with new friends }\end{array}$ & $\begin{array}{l}\text { Students cooperate in understanding } \\
\text { materials } \\
\text { Show openness when communicating } \\
\text { with peer } \\
\text { Encourage supports to fair competi- } \\
\text { tion in learning } \\
\text { Cooperate in offering solution to } \\
\text { problems among students in their class } \\
\text { interaction }\end{array}$ \\
\hline $\begin{array}{l}\text { Positive relation } \\
\text { between teacher } \\
\text { and students }\end{array}$ & $\begin{array}{l}\text { 1)Presence of collaborative leadership } \\
\text { 2)Teacher's attention outside the class }\end{array}$ & $\begin{array}{l}\text { Teacher acts as friend in handling } \\
\text { students' problems } \\
\text { Teacher empathizes with students' } \\
\text { personal life }\end{array}$ \\
\hline $\begin{array}{l}\text { Develop and en- } \\
\text { force class rules }\end{array}$ & $\begin{array}{l}\text { 1)Presence of learning design in the } \\
\text { form of lesson plans } \\
\text { 2)Presence of achievement reward } \\
\text { 3)Rules are develop democratically } \\
\text { 4)Presence of learning rules that create } \\
\text { learning climate that is secure and } \\
\text { controlled }\end{array}$ & $\begin{array}{l}\text { Each learning follows the lesson plan } \\
\text { given by teacher } \\
\text { Presence of reward from teacher to } \\
\text { students who are active in class } \\
\text { Class rules are written based on re- } \\
\text { sults of deliberation } \\
\text { Use class rules as guide in every class- } \\
\text { room activity }\end{array}$ \\
\hline
\end{tabular}

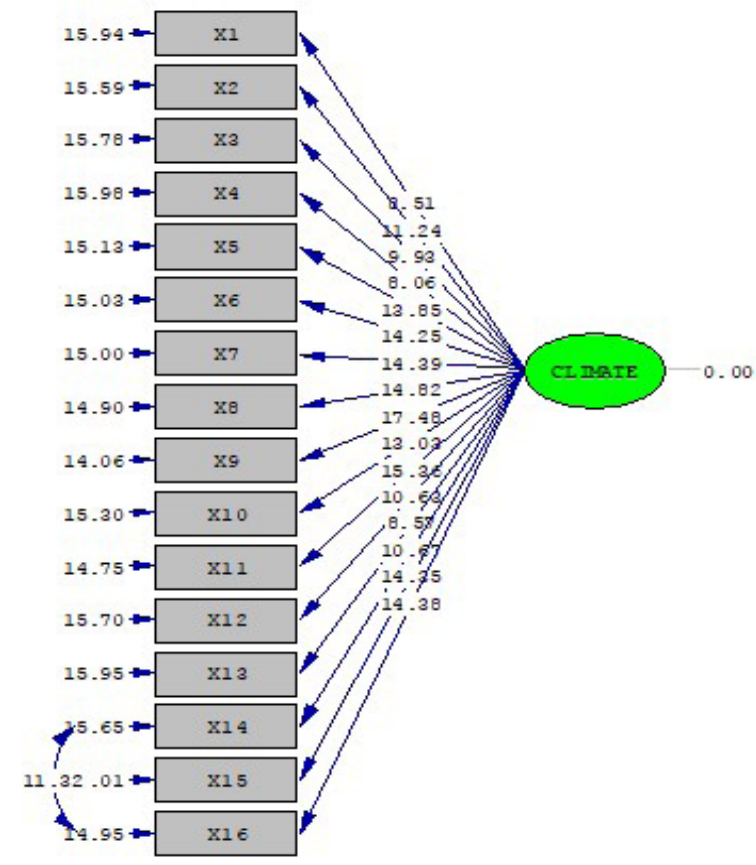

Figure 1. Analysis results of strength of item on geography learning climate variable. 
findings the research on Dimensions and Factors of Learning Climates of Contemporary Geography is a lot of things that can be utilized by policy makers and educational practitioners at the school level, through the implementation of geographic skills activities based on Factors and Indicators for SHS Geography Learning Climates, as illustrated in Table 1. Academic activities can proceed smoothly and achieve the objectives when there are efforts to create climates conducive for the running of effective education. The learning climate or situation that becomes a conviction, habit, and social-academic behaviour builds up an academic culture. Academic climate can be developed through good interactions among teachers, students, reward systems for achievement, supportive students' behaviours, disciplined practices, collaborative leaderships, collaboration among teachers, professional developments, collegial supports, and mutual objectives. Dimensions of the geography learning climates as studied in the study follows the contexts of the 1913 geography curriculum which uses the scientific approach. Operationally, the four dimensions and factors that are derived can be realized in a geographical learning that is directional. Mohan et.al [2015] describes geography as a complex science discipline that is focused on the characteristics, relationships, and spatial patterns of the activities of man and nature. Geography teaches about cultures, geopolitics, system of nature, resource distribution and uses, and the mapping of spatial data in order to understand more about the world. In order to learn geography, that is complex and wide, a learning climate is needed that gives comfortable room or climate for students in class. Every learning is unique for there are variables that have impacts on the class climate.

In order to achieve this condition, each factor in the dimensions must be recognized and explored further deeply as a preventive and curative measure in reaching the learning objectives and outcomes. Hergenhahn \& Olson [2010] states that a learning outcome is a behavioral change or a behavioral potential that is relatively permanent resulting from the learner's experiences. Slavin [2011] depicts learning, viewed from the cognitive side, as an unobservable mental process used by a person to learn and remember new information or competencies.

\section{Student-centred learning}

Results of the analysis of the dimension of student-centred learning are closely related with inquiry activities. Students are given the explorational opportunities to independently analyze the spatial relations of a phenomenon and process on the surface of the earth. This method facilitates students to understand problems, identify causes, and formulate findings in a descriptive form or draw a conclusion collectively in a small group. Students are grouped in accordance with their individual readiness and material contexts. The learning climate is one full of fun and joy. This student-centred dimension is oriented more to lifeskills so that students are competent in theory and practice in daily life.

Activities for the learning climate that is centred on the learners can refer to geographical skills that are relevant to the 2013 curriculum. The researcher designed alternatives for student-centred contemporary geography learning climate through the integration of the assessment activities of the geography learning under the 2013 curriculum with the opinions of Heffron and Downs [2012]. First, the ability of contextual learning to learn is an inseparable part in understanding geography problems independently and continuously. This competency is shown by the ability to ask geographic questions and acquire geographic information. For example, the teacher designs a learning session that asks students to determine the astronomic or geographic location of a phenomenon in the instructional material. The students are then asked to obtain geographic data through observation, surveys, or questionnaires.

Second, abilities to cooperate and communicate are for the students to be able to present ideas and solutions to problems. This competence is in line with Heffron's ideas by organizing geographic information and analyzing geographic information. An example of conducting these two activities can be for students to present geographic data by a map, diagram, or table. Students then are asked to create a pattern based on the data and analyze it by a regional approach. Based on the results of the analysis, students are asked to conclude or present the possible trends related to the geographic data.

Third, students are guided to make use of geographic technology such as the management of maps, image televiews, and geometric information system (GIS). Such competencies are in line with efforts and ways of answering geographic questions through geographic technology. Activities students can do are identifying geographic objects from a map, interpreting geographic objects from televiewing, or practicing the processes of GIS to analyze phenomena in the instructional material.

\section{Positive relation among students}

Classroom learning is always programmed in an instructional design in order that students learn actively and positive relation among students is emphasized up to the provision of learning resources [Dimyati and Mudjiono, 2002]. As a process, learning must be understood as a motivational venue to give learners experiences through the challenges and reinforments in it. Slameto [2010] states that learning is a process of the efforts by an individual to acquire changes in new behaviors as a whole, as a results of the individual's experiences in interacting with his environments including peers. In the same direction with that thought, Sri Rumini, et al [2006] have the opinion that one 
characteristic of learning is the emergence of changes in the cognitive, affective, psycho-motoric, competencies and their combination through experiences or practices as a result of the learner's positive interactions with his environments including peers. These thoughts are inclined to lead to learning as a positive interaction process between the learner and his environments to reach improvement in a variety of things towards happy life. This learner's positive interaction with the environment in all activities is a form of learning climate that emerges because it is designed or it happens spontaneously. The learning environment aspect can be physical or non-physical.

One of the research results of the present study shows that one dimension of the geographic learning climate is that which is designed for the learners to have positive interactions with the peer. The Exploratory Factor Analysis results have reduced the factor of positive relation among students can be related with: (1) applying the positive relation (mastery goal orientation), (2) appreciating students' relation by positive behaviours, (3) building up relation in games that encourage positive interaction, and (4) offering solutions to students' difficulties in their social dynamics and forming a web of new friends.

Some theorists like McGregor \& Elliot [2002]; Harackiewics, et.al [2002] and Elliot, [2005] have the same understanding on mastery goal orientation as a form of students' motivation to have positive learning behaviours in mastering the instructional material. They further propose that students oriented to mastery goals possess internal motivation arising from their inner awareness; while Church et.al [2001] expands the view that self-awareness is related to external environmental stimulation that is also positive, such as the positive relation with their environment. When the environmental climate is positive, students will be further enhanced to study more diligently, harder, and more seriously in mastering the learning material. In the study, the factor item of the application of positive learning behaviours as the realization of mastery goal orientation is a part of the dimension of positive relations among students in the geographic learning climate which is shown by students' efforts in cooperating to understand the instructional material. The context of cooperation is working together in understanding geographic aspects such as interpreting the pattern form of a phenomenon.

This second dimension, appreciating students' relations by positive behaviours, is understood as the students' attitudes in maintaining their social competencies. Buldur [2014] states that good relations among students by displaying behaviours of respecting each other are strongly related to the learning objectives in class. It is further added that the gender factor of the students does not cause significant differences in the achievement of the learning objectives. Cavanagh [2015] explains a model in which the students' abilities to learn is affected by their environmental situations. One example of such situations is one related to the students' attitudes and behaviours in class that is called interesting learning environment. In this study, an example of the learning climate behaviour which is relevant to the dimension item is giving the opportunity for the students to be open when communicating with the peer in the geography class.

The third item of the dimension of positive relations among students is building up relation in games which enhance positive interaction. Game playing helps students to feel happy and challenged in participating in the class learning. Aththibby and Alarifin [2015] state that instructional games give students enjoyment, fun, interest, and necessity; one of the effective strategies for the successfulness of the students in learning. Instructional games create learning climate which is interesting and enjoyable so as to raise active participation in learning. Students who are actively involved in class find it easy to achieve the learning objectives. Many games are available for classroom activities such as Brain Gym, Ice Breaking, Tournament, and others. No limitation is to be given for the choice of games in the instructional sessions in the geography class. The key word in the use of instructional games is the fair spirit of competition in the learning activities.

The last dimension is related to giving solution to students' difficulties in the social dynamics and forming a web of new friends. Students' capacities in facing classroom instruction are different. They participate in the learning activities as it is suitable with their readiness. A student's difficulty in getting along with others has an impact on his classroom activities. Soltanzadeh et al [2013] and Yurdabakan [2012] states that students' learning activeness has a significant relation to their motivation for academic achievement. Mahmudah [2017] states that students' self-confidence towards their capacities to achieve in the future is closely related to the climate of the learning organization. Learning climate, which gives the opportunities for the students to offer solutions and interact among each other, is designed through active learning. In their cognitive development, senior high school students are at the formal-operational level. Slavin [2011] states that this cognitive development level is characterized by the continuous growth of understanding and abilities. The young adults begin to be aware of their limitation in their thinking. Slavin further adds that they need experiences with complex problems, demands of formal learning, and changes and contradiction of ideas against their peer so that their formal operational reasoning develops. Hergenhahn \& Olson [2010] give support to the idea that young adults have more logical thinking processes. The presence of a system and friends endorse students to create classroom climates that are solutive for them. Learning is so designed to give the students the opportunities to offer each other solutions to problems in their interaction in the classroom. 


\section{Positive relation among teachers and students}

The presence of collaborative leadership and teachers' concern outside the classroom become a good beginning of conducive classroom climates. Participation of the teachers and students contribute to the formation of the learning climate [Church, Elliot, \& Gable, 2001]. Santrock [2008] states that a teacher will have great efforts to apply all his capabilities in running his class instruction when there is a conducive learning climate. All his potentials and abilities will be given for his teaching, educating, and guiding the students. In the same manner, students will be more challenged to participate in the instructional process as a result of the optimalization of the teacher's potentials. They will have high motivation in learning to master the material [Locke \& Latham, 1990]. On the contrary, poor relation among teachers and students bring about unfavourable learning results. Lapper et.al [2005] state that, when the teacher is not enthusiastic in teaching that demotivates students, students will on their turn have unsatisfactory learning achievement. According to Tumanggor and Dariyo [2015], dynamic cooperation among teacher and students through dynamic social interaction will create perseverance in facing various problems of academic resilience. The teacher can make efforts in building up relation by taking the role as a friend in facing the students' problems. Furthermore, teachers empathize with students' personal life.

\section{Developing and enforcing classroom rules}

Classroom rules are enforced in order to create a conducive climate fort the attainment of instructional objectives. In the study, the formats of the factor items in the climate dimension are closely related to the expectations of the 2013 curriculum. Classroom learning rules resulted from the study are: (1) There should be a learning design in the form of a lesson plan; (2) Normatively, the teacher designs a system for achievement rewards; (3) Rules are decided democratically, and (4) Learning rules are developed in order to create a lwarning climate that is secure and controlled.

Operationally, every geography learning complies with the lesson plan designed by the teacher. Teachers are able to use all their knowledge and skills to manage and support students in the learning process. The lesson plan developed by the teacher must teach the students thinking skills [Newman, 1990], spatial thinking skills [NRC, 2006] and [Jo, Berdnarz and Metoyer, 2010], and adopting spatial representation and geographical technologies [Jo and Berdnarz, 2014]. A reward system must be devised by the teacher for students who are active in the classroom learning. Classroom rules must be developed as a result of deliberation and they must be used as a guide ways for each of the instructional activities.

\section{Conclusion}

The exploratory factor analysis results give four dimensions with 16 factor items for contemporary geography learning climates at the senior high school, namely: (1) student-centred learning with 6 factor items, (2) positive relation among students with 4 factor items, (3) positive relation among teachers and students with 2 factor items, and (4) development and enforcement of classroom rules with 4 factor items.

In the study, dimensions and factors of classroom climates have not completely measured the specific characteristics of geographic content materials as they are prescribed in the geography competences. Efforts are still needed in developing geography contexts as commonly practiced at the present time. The present study has not mapped the specific learning climates for each of the basic competences and content materials addressed in the curriculum. It is therefore advisable that further research be devised to specifically develop the basic competencies or content-material mapping. It is also advisable to include other research variables such as learning models, learners' self-regulations, and work performance of teachers as key persons of the learning process.

\section{Acknowledgements}

The writer owes gratitude to the Faculty of Social Sciences of the University of Yogyakarta for the funding of the study. Thanks also to the teachers, head master and supervisors for earnestness in being fully involved in the research.

\section{References}

Aiken, Lewis R. (1996). Rating Scales and Checklist: Evaluation Behavior Personality, and Attitude. New York: John Wiley \& Sons Inc.

Anthamatten, Peter. (2010). Spatial thinking Concepts in Early Grade-Level Geography Standards. Journal of Geography 109: 169-180.

Aththibby, Arif Rahman, Alarifin, and Dedi Hidayatullah. (2015). Pengaruh Permainan dalam Pembelajaran Fisika Terhadap Motivasi Belajar Peserta Didik. JRKPF UAD Vol.2 No.2 Oktober 2015, 38-41.(in bahasa Indonesia).

BPSDM. (2014). Buku Pedoman Guru: Peminatan Ilmu Pengetahuan Sosial, Geografi. Jakarta: BPSDM.(in bahasa Indonesia).

Buldur, Serkan. (2014). An Investigation of the Relationship between the Students' Perceptions about Classroom Assessment Environment and their Achievement-Goal Orientations: Gender Perspective. Education and Science 2014, Vol 39, No 176, 213-225.

Cavanagh, Robert F. (2015) A unified model of student engagement in classroom learning and classroom learning environment: one measure and one underlying construct. Learning Environ Res (2015) 18:349-361. 
Church, M. A, Elliot, A.J \& Gable, S.L (2001). Perceptions of classroom environment, Achievement Goals and Achievement Outcomes. Journal of Educational Psychology. Vol.93, No.43-54.

Church, M. A, Elliot, A.J \& Gable, S.L (2001). Perceptions of classroom environment, Achievement Goals and Achievement Outcomes. Journal of Educational Psychology. Vol.93, No.43-54.

Cox (2006). The Quality of Instructional Program. Alaska: National educational Program. Diambil dari: www. Ak.nea.org/excelence/coxquality.

Davidson, Gill. (2002). Planning for enquiry. In Magie Smith (Editor), Book of Aspects of Teaching Secondary Geography, Perspectives on practice, pp 77-92. London. RoutledgeFalmer.

Dimyati \& Mudjiono. (2002). Belajar dan Pembelajaran. Jakarta: Rineka Cipta.(in bahasa Indonesia)

Elliot, A. J. (2005). A Conceptual History of the Achievement Goal Costruct. In A. J. Elliot \& C.S. Dweck, Handbook of Competence and Motivation, pp.52-72. New York: The Guilford Press.

Falsario, Herminia N, Raul F. Muyong, \& Jenny S. Nuevaespaña (2014). Classroom Climate and Academic Performance of Education Students. Presented at the DLSU Research Congress. De La Salle University, Manila, Philippines March 6-8, 2014.

Harackiewics, J. M, Barron, K. E, Pintrich, P. R, Elliot, A.J \& Thrash, T.M (2002). Revision od Achievement Goal Theory: Necessary and Illuminating. Journal of Educational Psychology, Vol.94, p.638-645.

Heffron, Susan Gallagher and Downs, Robert M. (2012) Geography for Life: National Geography Standards. Washington D.C. National Council for Geographic Education.

Hergenhahn \& Olson. (2010). Theories of Learning (Teori Belajar) (alih bahasa: Tri Wibowo B. S.). Jakarta: Kencana Prenada Media Group.

Hopkin, John. (2011). Geography in Progress. Geography. Vol. 96 Part 3, Autumn. pp. 116-123

Janelle Donald G. dan Goodchild Michael F. (2010). Toward Critical Spatial Thinking in The Social Sciences And Humanities. GeoJournal 75. 3-13.

Jo, Injeong \& Bednarz, Sarah Witham. (2014) Dispositions Toward Teaching Spatial thinking Through Geography: Conceptualization and an Exemplar Assessment. Journal of Geography, 113: 5. 198-207.

Jo, Injeong, Bednarz Sarah, \& Metoyer Sarah. (2010). Selecting and Designing Questions to Facilitate Spatial thinking. The Geography Teacher 7 (2), 4955.

Kementerian Pendidikan dan Kebudayaan. (2016). Peraturan Menteri Pendidikan Nasional nomor 23 tahun 2016 tentang Standar Proses Pendidikan Dasar dan Menengah. (in bahasa Indonesia).

Kirby John R dan Lawson Michael J (editor). (2013) Enhancing the Quality of Learning: Dispositions,
Instruction, and Learning Processes. New York: Cambridge University Press.

Lambert, David dan Morgan, John. (2010). Teaching Geography (11-18): A Conceptual Approach. New York: Open University Press.

Lapper, M. R, Corpus, J. H \& Iyengar, S. I. (2005). Intrinsic and Extrinsic Motivational Orientation in the Classroom: Age Differences and Academic Correlates. Journal of Educational Psychology, Vol.97, No.2, 184-196.

Lee, Jongwon and Bednarz, Robert. (2012). Components of Spatial thinking: Evidence from a Spatial thinking Ability Test. Journal of Geography 111: 15-26.

Locke, E. A \& Latham, G. P (1990). A Theory of Goal Setting \& Task Performance. New Jersey, Englewood Cliffs: Prentice Hall.

Mahat Hanifah, Yazid Saleh, Mohmadisa Hashim and Nasir Nayan. (2016). Model Development on Awareness of Education for Sustainable Schools Development in Malaysia. Indonesian Journal of Geography, Vol. 48 No. 1, June 2016: 37 - 46.

Mahmudah Siti, Budiman Christiananta, dan Anis Eliyana. (2017). Organizational Climate and Student Achievement: A Study at The Vocational College in Surabaya, Indonesia. International Journal of Social Science and Technology Vol. 2 No. 1; January 2017. 34-50.

McGregor \& Elliot, (2002) Achievement Goals as Predictors of Achievement-Relevant Processes Prior to Task Engangement. Journal of Educational Psychology, Vol.94, No.2, p.381-395.

Mohan Lindsey, Mohan Audrey, and David Uttal. (2015). Research on Thinking and Learning with Maps and Geospatial Technologies. Geo progressions. USA: American Association of Geographer.

Mooi, Erik and Sarstedt, Marko. (2014). A Concise Guide to Market Research: The Process, Data, and Methods Using IBM SPSS Statistics (2nd Edition). London: Springer.

Mucherah, Winnie and Frazier, Andrea D. (2003) How Teachers Perceive Their Classroom Environments and Student Goal Orientation: A Look into High School Biology Classrooms in Kenya. British Journal of Education, Society \& Behavioural Science 3(1): 1-17, 2013.

Mukminan. (2011). Evaluasi Implementasi KTSP Pada Pembelajaran Geografi SMA di kota Yogyakarta. Cakrawala Pendidikan, November 2011, Th. XXX, Nomor 3. 490 - 504.

National Research Council. (2006). Learning to think spatially GIS as a support system in the K-12 curriculum. Washington, DC: National Academy Press.

Newmann, F. M. (1990). Higher order thinking in social studies: A rationale for the assessment of classroom thoughtfulness. Journal of Curriculum Studies 22 (1): 41-56. 
Nursa'ban, Muhammad, Suparmini, dan Sriadi. (2012). Evaluasi Kompetensi Pedagogik Guru Geografi SMA Kabupaten Bantul. Socia. Volume 11, nomor 2, September 2012. 165-182.(in bahasa Indonesia)

Peraturan Pemerintah Nomor 19 Tahun 2005 Tentang Tentang Standar Nasional Pendidikan .(In bahasa Indonesaia).

Rawling, E. (2000) National Curriculum geography: new opportunities for curriculum development, in A. Kent (ed.) Reflective Practice in Geography Teaching, London: Paul Chapman Publishing.

Rohani, Ahmad. (2004). Pengelolaan Pengajaran. Jakarta. PT Rineka Cipta.(in bahasa Indonesia).

Rumini. Sri. dkk. (2006). Psikologi Pendidikan. Yogyakarta. UNY Press.(in bahasa Indonesia).

Rusman. (2010), Model-Model Pembelajaran, Jakarta: Raja Grafindo Persada.

Santrock, J. W. (2008). Educational Psychology. (3rd edition). Boston: McGraw-Hill.

Sukmadinata, Nana Syaodih. 2005. Landasan Psikologi Proses Pendidikan, Bandung: PT Rosda Karya.(in bahasa Indonesia)

Slameto (2010). Belajar dan Faktor-faktor yang Mempengaruhinya. Jakarta: Rineka Cipta.(in bahasa Indonesia).

Slavin, Robert E. (2011). Psikologi Pendidikan Teori dan Praktik (Alih Bahasa: Marianto Samosir). Jakarta: Indeks. (in Bahasa Indonesia)

Soltanzadeh, Liele, Seyed Reza Nazari Hashemi dan Sakineh Shahi. (2013). The effect of active learning on academic achievement motivation in high schools students, Department of Management, Khozestan Research and Science Branch, Islamic Azad University,Shahid Beheshti University,Shahid Chamran University of Ahvaz, Iran Scholars Research Library Archives of Applied Science Research, 2013,Journals, 5 (6):127-13.
Suhardjo, A.J. dkk. (2013). Filsafat Sains Geografi. Yogyakarta. Deepublish.(in bahasa Indonesia).

Tumanggor, Raja Oloan and Dariyo, Agoes [2015] Pengaruh Iklim Kelas Terhadap Resiliensi Akademik, Mastery Goal Orientation dan Prestasi Belajar. Prosiding. Seminar Psikologi \& Kemanusiaan. Psychology Forum UMM, ISBN: 978-979-796-324-8, pp 262-268. (in bahasa Indonesia).

Withers, Charles W.J. (2009). Place and the "Spatial Turn" in Geography and in History. Journal of the History of Ideas, Volume 70, Number 4 (October 2009). Pp 637-658 .

Yurdabakan Irfan, Mustafa Er, Ugur Altunay. (2012). The Effects Of Active Learning On Foreign Language Self-Concept And Reading Comprehension Achievement, Turkish Air Force Academy, Dokuz Eylul University, International Journal On New Trends In Education And Their Implications. October 2012 Volume: 3 Issue: 4 Article: 04 ISSN 1309-6249. 